\title{
A PROPRIEDADE NO DIREITO MUÇULMANO: UMA ANÁLISE COMPARATIVA COM O DIREITO BRASILEIRO
}

\author{
PROPERTY IN MUSLIM LAW: \\ A COMPARATIVE ANALYSIS WHIT \\ BRAZILIAN LAW
}

Kelly Bruch*

Resumo: O presente artigo trata das fontes do direito muçulmano e de sua noção de direito real. Utilizando-se do método do direito comparado, o artigo é trabalhado em duas partes. A primeira trata dos fundamentos do direito muçulmano, contextualizando historicamente sua formação, bem como as fontes utilizadas para sua aplicação. A segunda parte trata do direito real, nos âmbitos da posse e propriedade, e faz um paralelo entre alguns institutos do direito brasileiro e do direito muçulmano. O objetivo deste artigo não é esgotar o assunto, mas fazer uma breve introdução que possa auxiliar a compreender este sistema jurídico, hoje em evidência, com base na comparação com o direito brasileiro.

Palavras-chave: Direito Islâmico; fontes do direito; direito de propriedade; direito comparado; Islã.

* Graduada em Direito pela Universidade Estadual de Ponta Grossa (2001), Especialista em Direito e Negócios Internacionais pela UFSC (2004), Mestre em Agronegócios pelo CEPAN/UFRGS (2006), Doutora em Direito pela Université Rennes I, France em co-tutela com a UFRGS. Desde 2010, professora da Faculdade Meridional - IMED e da Faculdade Iguaçu, professora colaboradora no Programa de Mestrado Profissional em Biotecnologia e Gestão Vitivinícola da UCS. 
Abstract: This article discusses the sources of Islamic law and its concept of real right. By using the method of comparative law, the article is divided into two parts. The first deals with the fundamentals of Islamic law, with an historical approach and explaining the sources used to its application. The second part deals with the real rights in the scope of position and propriety, and makes a parallel between some institutes of the Brazilian law and Islamic law, especially in co-ownership. The objective of this article is not to exhaust the subject, but to make a brief introduction that may help to understand the Islamic legal system based on comparison with the Brazilian law.

Keywords: Islamic law; sources of law; property rights, comparative law, Islam.

\section{Introdução}

O termo Islan vem das palavras árabes Salam, salama, que significa repouso, paz. Este é o objetivo final de quem busca e segue o Islan. Para compreender o direito muçulmano faz-se necessário entender como atua esta fé, quais seus pilares, onde ela surge e como se estrutura.

Segundo Pansier e Guellaty (2000) são cinco os pilares que sustentam o Islan. O primeiro é o sahad, a fé em um Deus único (Allah), e a crença de que Muhammad é o profeta enviado à Terra. O segundo é o salat, o culto e a oração. Deve-se rezar cinco vezes ao dia, com a fronte voltada para Meca, seguindo-se para tanto o ritual de purificação prévia, prostração, atitude, silêncio e meditação. $\mathrm{O}$ terceiro é o sawan, o jejum, que deve ser realizado nos dias 28 a 30 do mês de Ramadan segundo o calendário islâmico. Neste período não se deve beber, comer, fumar, ter relações sexuais, dentre outros. O quarto é o zakat, a caridade. Esta se traduz em tornar fato as palavras, ou seja, agir sempre de forma caridosa. O quinto é o hâdjdj, a peregrinação que todo o mulçumano deve fazer ao menos uma vez na vida à Meca se tiver condições. 
A religião islâmica surge na Arábia Saudita, oriente médio, grande centro do comércio internacional e canal de comunicação para muitas partes do mundo. Esta localização permitiu que esta religião fosse levada para diversas partes do mundo, sendo que hoje podemos encontrar seguidores nos cinco continentes.

O livro sagrado do Islan é o Qoran, que tem por significado a revelação da palavra de Deus. É este que, somado às demais fontes do direito, rege a vida política, econômica, social e familiar daquele que vive sob a égide do Islan.

Visando buscar um entendimento da concepção do direito muçulmano, o presente trabalho se divide em duas partes: os fundamentos do direito muçulmano e o direito de propriedade segundo o direito muçulmano, em uma análise comparativa com o direito brasileiro.

A primeira parte compreende a história do direito muçulmano, onde se busca brevemente tratar de Muhammad e do surgimento do Islan, das escolas do direito muçulmano e da expansão deste direito. Num segundo momento trabalham-se as fontes do direito muçulmano, primeiramente as fontes primárias, depois as fontes secundárias e por fim dos elementos que às ligam à aplicação do direito.

A segunda parte trata primeiramente da posse e propriedade, falando dos fundamentos da propriedade, da extensão do direito de propriedade e por fim da concepção de posse. Num segundo momento são trabalhados alguns institutos do direito de propriedade muçulmano, especialmente comparando-se este com institutos semelhantes encontrados no direito brasileiro. Basicamente são abordados o awaqaf, a co-propriedade, e as utilidades e garantias do direito de propriedade.

O objetivo é apresentar um panorama geral sobre este sistema de direito que vem se expandindo por meio da religião e hoje convive com os demais sistemas jurídicos em várias partes do mundo, inclusive no Brasil.

Optou-se por trabalhar os direitos reais em face da tratativa bastante diversa que o Islan dá para este instituto, o qual baliza a propriedade islâmica como sendo um empréstimo dos bens de Deus. 


\section{Fundamentos do direito Muçulmano}

Neste primeiro capítulo trata-se da história do direito muçulmano e da própria religião muçulmana, que são intrinsecamente ligadas. Inicia-se com a história de Muhammad, após são apresentadas as quatro principais escolas de direito muçulmano e por fim aborda-se a expansão desta religião e por conseqüência as regras inerentes a esta na atualidade.

Num segundo momento abordam-se as fontes que dão suporte ao direito muçulmano. Inicia-se pelas fontes primárias, em cuja classificação se encontra o Qoran e a Sunna, que formam a Shari’a. Dentre as fontes secundárias encontram-se a ijma, kiyas, urf, amal, kanun e ijtihad. Entre os elementos de conexão encontram-se a fatwa, tafsir, istahsan e maslaha.

\subsection{História do direito}

\subsubsection{Muhammad}

O profeta da religião muçulmana, Muhammad, ficou órfão aos seis anos de idade e foi criado pelo seu avo Ahmed Bem Mottalib, e depois da morte deste pelo seu tio Abou Talib juntamente com seu primo Ali. Casou-se com uma rica viúva, Khadija, que tinha um negócio de caravanas. Um dia, trabalhando sozinho, o Anjo Gabriel lhe apareceu e lhe revelou o Qoran - que significa revelação, e determinou que este o transmitisse aos outros homens. Em conseqüência o Qoran se tornou imutável, pois ninguém pode mudar a palavra de Deus (PANSIER e GUILLATY, 2000).

Muhammad, juntamente com sua esposa, passou a transmitir a mensagem de Deus aos habitantes de Meca. Seus primeiros discípulos foram seus amigos Abou Bakr, Omar, seu primo Ali e sua filha adotiva Zaid (PANSIER e GUILLATY, 2000).

Ele pregou o Deus único que recompensa os bons e pune os maus. Segundo o ensinamento, no dia de sua morte o homem se torna inconsciente até o Julgamento, quando então ressuscitará para ser julgado (PANSIER e GUILLATY, 2000). 
Em Meca sua pregação não foi bem aceita e ele foi obrigado a partir para a vila de Yathrib, hoje conhecida como Medina Madinat na Nabi - que significa em árabe vila do profeta. Esta mudança é conhecida como Hegire, e dá início à era muçulmana, esta ocorre em entre $1^{\circ}$ e 24 de setembro de 622 da era cristã (PANSIER e GUILLATY, 2000).

Após esta partida segue-se um período de luta muitas entre as vilas de Yathrib e Meca que resulta primeiramente em derrotas para o profeta. Mas aos poucos Muhammad recupera seu poder e autoridade. Em 628 d.C. morre a esposa de Muhammad. Ele então se casa com a filha de uma importante pessoa de Meca e em 630 d.C. ele marcha até Meca onde ele entra na cidade sem combate e estabelece finalmente o Islan (PANSIER e GUILLATY, 2000).

Mohamed morre em 632 d. C., vitima de uma forte febre, e sua morte dá início a uma luta pela sua sucessão. Segundo o Islan, a ordem de poder para a condução da religião muçulmana é dada por Deus ao Profeta, deste ao Calife, que é um seguidor próximo do Profeta, e deste ao Emir. Com a morte do Profeta tem início o Califat. Como Muhammad não deixou ninguém em seu lugar, seu primo Ali se torna o Calife e é assassinado pelos seguidores que não concordavam com sua indicação. Os seguidores de Ali forma o segmento Chiita, e os seguidores que se opunham a Ali formam o segmento Sunnita. Este último é o que hoje prepondera dentro da religião islâmica e o presente estudo se embasa nas escolas provenientes do segmento Sunnita (PANSIER e GUILLATY, 2000).

Com sua morte, Muhammad deixa o Qoran, que é a revelação da palavra de Deus, e a Sunna, que é a interpretação do Qoran pelo profeta.

\subsubsection{Escolas do direito muçulmano}

O estudo do direito muçulmano segue a partir dos dois pilares, o Qoran e a Sunna, que formam a Shari'a, a fonte primária do direito, e dela derivam as fontes secundárias. 
Este estudo vem ocorrendo ao longo do tempo iniciando-se logo após a morte de Muhammad. Quatro escolas ortodoxas são predominantes no direito muçulmano, sendo que estas formam os quatro ritos básicos adotados na maioria dos países que seguem a religião e por conseqüência o direito muçulmano: hanefita, malekita, shafeita e hanbalita.

A escola hanefita tem como seu Iman, ou seja, seu sábio criador Abu Hanifa. É uma escola baseada na ahl al-ra'y, ou seja, na razão, e por isso são conhecidos como gente da razão. Sua principal diretriz é interpretar, quando necessário, a Sharia, por meio da razão. Esta escola recepciona os institutos da kiyas, que significa analogia e da istahsan, que significa equidade (PANSIER e GUILLATY, 2000).

A escola malekita tem como seu Iman Malik ibn Anas. É uma escola baseada na ahl al Sunna, ou seja, na tradição, e por isso são conhecidos como gente da tradição. Sua principal diretriz é interpretar, quando necessário, a Shari’a, por meio da tradição que vem sendo passada de geração em geração. Tem o Ritds al Muwatta, que significa livro da via sem obstáculos ou do caminho reto. Esta escola é mais objetiva e busca não fugir do disposto na Shari’a. É uma das escolas predominantes nos países que adotam a religião muçulmana (PANSIER e GUILLATY, 2000).

A escola shafeita tem como seu Iman Muhammad ibn Idhis Al-Shafei. É uma escola baseada na ilm al fiqh, ou seja, na ciência racional do direito, e busca conciliar a tradição como trabalho especulativo. Sua principal diretriz é buscar o justo médio (PANSIER e GUILLATY, 2000).

A escola hanbalita tem como seu Iman Ahmad Muhammad ibn Hanbal. É uma escola baseada na defesa das tradições e na interpretação literal da lei (PANSIER e GUILLATY, 2000).

Existem ainda outras escolas de menor expressão como a de Al-Awzai, a de Al-Taban e a de Al-Isfahani, dentre outras.

Uma questão importante é que dentre elas nenhuma é necessariamente considerada certa ou errada. Mas, para a resolução de um caso concreto, se for adotado alguma jurisprudência ou in- 
terpretação de uma das escolas, todo o caso deverá ser olhado do ponto de vista da escola escolhida. Portanto, há necessidade de se manter a coerência.

\subsubsection{Caráter global da expansão}

Como já colocado, o Islan nasce em uma região estratégica do oriente médio, e em pouco tempo se expande para o oriente, a Ásia, a África, a Europa. Esta expansão se dá pela própria natureza deste ser popular, plurinacional, de fácil entendimento. Com sua expansão também a língua árabe se expande (PANSIER e GUILLATY, 2000).

Segundo o Islan, aquele que nasce muçulmano, ou se converte, tem seu direito regido pelo Qoran, sua vida pública e privada são regradas pela religião, independente de onde estejam. Há nos países muçulmanos o respeito aos que não professam esta religião, inclusive o respeito a utilizar a lei da religião de cada pessoa para julgá-la.

Segundo Pansier e Guellaty (2000) as cidades muçulmanas não são confundíveis com outras cidades, pela sua organização e disposição. Nos países muçulmanos as funções públicas, intrinsecamente ligadas com a religião são divididas da seguinte maneira: o Sultão, que é o comandante dos crentes, é o soberano do estado independente; Caïd ou cheikh é o governador da província; Pacha é o governador da cidade; e Vizirs são os ministros do governo.

Atualmente existem países predominantemente muçulmanos na: Arábia, tais como Kwait, República do Yeme, Emirados do Golfo Pérsico; na África, tais Tunísia, Lívia, Argélia, Marrocos, Egito, Sudão, Mauritane, Somália, Mali, Nigéria, Niger, Guiné; na Europa a Albânia; Repúblicas da Ex-União Soviética, tais como Azerbajão, Kazaquistão; e Turquia (PANSIER e GUILLATY, 2000).

$\mathrm{Na}$ Líbia há uma população mista. Há também países com expressiva população muçulmana: algumas partes da China, Israel, Chipre, Etiópia, Tchad, Madagascar, África do Sul, repúblicas afri- 
canas que se encontram no oceano índico, Denia, Zimbábue, Índia, Tailândia, Vietnam, Filipinas, e nos Balkans, na Bósnia, Sérvia, Bulgária, Macedônia, Montenegro, Croácia. Alem disso há minorias imigrantes na Europa, na Grã Bretanha, Alemanha, França, Suíça, Itália (PANSIER e GUILLATY, 2000).

Por fim vale ressaltar que hoje também se nota uma grande transformação do próprio direito muçulmano, adaptando-se à realidade de um mundo globalizado, e necessitando rever seus fundamentos. No presente trabalho serão tratados dos institutos na sua forma tradicional, sem considerar estas novas transformações.

\subsection{Fontes do Direito}

\subsubsection{Fontes primárias}

As fontes primárias do direito muçulmano são o Qoran mais a Sunna que, somados, formam a Shari'a. Sob a égide destas normas o Islan estabelece a submissão completa à vida comunitária islâmica: vida pública, status pessoal, status patrimonial e religião. Sem reserva ou discussão, esta submissão não é questionável ou retratável, sob pena de vir a ser um renegado aquele que não a seguir.

\section{a) Qoran}

A primeira fonte é o Qoran. Sendo a revelação da palavra de Deus, este trata de todos os comportamentos do muçulmano, trazendo todos os elementos idiossincráticos e indiscutíveis do Islan, regula toda a vida pública e privada do muçulmano.

Segundo seus fundamentos o Qoran é definitivo e imutável; não é um código ou uma obra jurídica doutrinária, pois dos seus 6219 versos apenas 600 falam de regras de direito; não é uma obra de intelectuais ou teólogos, sua linguagem de fácil compreensão se 
dirige ao povo pregando a igualdade, fraternidade e solidariedade de todos os muçulmanos, ricos e pobres; por fim, consagra a legitimidade e autoridade do profeta e de seus sucessores que são os depositários da palavra de Deus (ESTEVEZ BRASA, 1981).

É interessante ressaltar que o Qoran não foi escrito por Muhammad, mas por seus sucessores. Desta maneira, as novas leituras e comentários (tafsir) feitos por seus sucessores acabam por integrá-lo. É um veículo de união para o mundo islâmico, uma obra literária e instrumento para difusão da língua árabe (ESTEVEZ BRASA, 1981).

\section{b) Sunna}

A Sunna é a adaptação do que não estava previsto no Qoran, mas que foi interpretado de acordo com este e com a tradição de Muhammad. A Sunna traz originalmente a Sunnat al qaul, que é a ponderação do profeta, a Sunnat al fil, o dizer do profeta, e a Sunnat al takhir, que é a aprovação tácita do profeta de uma determinada situação. Este conjunto forma os hadith, que são os versos que compõe a Sunna. Por ser proveniente diretamente do profeta, é infalível e tão importante quando o Qoran (ESTEVEZ BRASA, 1981).

Os hadith representam os ditos e feitos do profeta, em suma. Estes ditos vêm de uma cadeia de pessoas que os transmitiu, que é a silsilat. A coerência desta cadeia de pessoas é que garante a veracidade da transmissão dos hadith (ESTEVEZ BRASA, 1981).

Os hadith, conforme a sua cadeia de transmissão, podem ser classificados em sahih - que são os perfeitos; hasan - que são bons; e da'if - que são os imperfeitos. A ilm ao-hadith, que é a ciência dos hadith, que estuda a veracidade da cadeia de pessoas que transmitiu os hadith e os classifica conforme a designação acima exposta (ESTEVEZ BRASA, 1981).

A principal finalidade da Sunna, e, portanto dos hadith, é completar as lacunas por ventura existentes no Qoran. 


\subsubsection{Fontes secundárias do direito}

Para compreender as fontes secundárias do direito, que são aquelas que surgem das tradições e costumes, do consenso da comunidade e das ponderações dos sábios, faz-se necessário compreender quem são as pessoas que podem validar uma fonte secundária.

Em regra existem os alim, que são os sábios do direito. Ele pode ser conhecido por diversas designações, tendo em vista as fontes de direito que eles elaboram. Os mudjtahidin são os sábios de uma das escolas, já expostas. São considerados juristas teólogos e elaboram os ijma, que são o consenso da comunidade. Os mufti são os sábios conhecedores da Shari'a. Eles elaboram os fatwa, que são opiniões ou pareceres que podem ser utilizados em sentenças. Os muqallidin, seguidores dos mudjtahidin, elaboram a tafsir, que é a explicação e compreensão da lei divina. O qadi é o juiz, que elabora as sentenças, muitas vezes faz papel de notário, firma contratos, dentre outros (ESTEVEZ BRASA, 1981).

a) Ijma

O ijma é o consenso da comunidade. Segundo dispõe o Qoran: meu povo jamais poderá ser unânime no erro. Assim, quando há um consenso na comunidade, que é representado pelo consenso dos sábios, este se transforma num ijma e pode ser seguido como uma interpretação do Qoran. O ijma não pode conter versos do Qoran. Trata-se de um dogma que se forma mediante o consenso unânime e praticado constantemente pelos juristas e designa um uso, uma regra de direito. Desta maneira, quando uma solução não pode surgir da lei, será o consenso da comunidade que demonstrará a solução, que provém dessa coincidência de opiniões para resolveram de forma concreta um assunto determinado (ESTEVEZ BRASA, 1981).

A regra procedente do ijma será estabelecida quando haja sido dada a conhecer de forma conjunta pelos mudjtahidin que participaram da discussão e elaboração, ou de forma separada sendo difundida por apenas um dos mudjtahidin, mas que não seja contradita pelos outros. Ela assegura à Comunidade Muçulmana a integração 
de distintas opiniões, o reconhecimento de novos princípios que vem surgindo no curso dos tempos e a adequação do novo direito à sociedade e da sociedade às normas (ESTEVEZ BRASA, 1981).

\section{b) Qyyas}

A qyyas é a analogia. Ela é feita por meio de um tafzir que é um comentário que visa explicar e compreender a lei. Ela deve ser feita por um mudhatahidin. Por ser produto da razão humana ela não é infalível. Em regra há duas formas de analogia: a analogia legal, que compara o caso concreto com outros casos; e a analogia de direito, que compara aplicações da lei. Mas não se pode fazer analogia com um caso que proceda de outra regra proveniente de analogia e não da análise da própria lei. Na realização da analogia, devem ser identificar três pontos: o texto legal, a questão para resolver e o nexo entre eles. Este nexo será a 'illa, que é a razão de ser da lei. Ou seja, a lei se aplica a este caso por que a razão de ser da lei a este caso contempla e assim o permite. Contudo a analogia não pode modificar a lei e, muito menos, os desígnios de Deus, como nenhuma fonte secundária em regra pode (ESTEVEZ BRASA, 1981).

\section{c) Urfe amal}

Os urf são os usos e costumes, e o amal é a jurisprudência. Há um constante processo de sedimentação dos usos e costumes e das resoluções judiciais. Estando os usos e costumes avaliados pelo consenso comunitário, ele pode ser transformado em ijma (ESTEVEZ BRASA, 1981).

Trata-se de uma fonte auxiliar do direito que vale mais para adequar a lei às necessidades e reclames imediatos que para modificá-la, substituí-la ou ab-rogá-la, embora isso possa vir a acontecer. Pode se assemelhar mecanismo ao precedente adotado nos países que tem como sistema jurídico o common law. Não há um divórcio entre as regras do costume e as normas jurídicas, já que ambas se completam mutuamente e aqueles países onde prevalece o direito escrito e estável, recorrem, sem embargo, ao costume quando devem resolver em concreto uma determinada situação que não encontra resposta imediata na lei (ESTEVEZ BRASA, 1981). 


\section{d) Jurisprudência}

A jurisprudência é formada do urf - usos e costumes, do fatwa - opinião ou parecer do mufti e do amal - que são as decisões judiciais. Este conjunto forma cada decisão judicial e, portanto a jurisprudência.

Para a jurisprudência ser válida como fonte de direito o pronunciamento deve responder a algum interesse geral, ou à necessidade particular submetida à decisão e contar com o aval de dois testemunhos honoráveis ou um científico reconhecido. Além disso, toda a sentença deve fundar-se na opinião de um mufti. Todo este cuidado se deve por que a origem divina da norma não pode ser objeto de revisão pelo homem (ESTEVEZ BRASA, 1981).

\section{e) Kanun}

O kanun é a nova lei. Elas são elaboradas para regulamentar as situações que não se encontram nas fontes primárias. São elaboradas e sancionadas muitas vezes por assembléias legislativas. Para admitir a kanun, entende-se que a autoridade política, ao emitir ordenações, leis, disposições ou regulamentos, tenha consultado a mais alta autoridade em matéria de ciência islâmica, de tal modo que o poder de polícia próprio de toda a administração não caia em excesso. A nova lei também trata da regulamentação das leis que se aplicam aos não muçulmanos que se encontram dentro de um país árabe, com a finalidade de aplicar para ele a lei de sua religião (ESTEVEZ BRASA, 1981).

\section{f) Ijtihad}

O ijtihad é a doutrina. Ela busca sistematizar um mecanismo intelectual com a finalidade de legitimar uma prática que traga solução aos casos novos e que estão ligados aos princípios gerais contidos ou decorrentes das fontes primárias. Trata-se de construir um método utilizando a razão a serviço da religião. Ou seja, a construção de uma teoria de relações entre a revelação e a razão humana. Se for aceito e praticado de forma coletiva, pode vir a se transformar em um ijma (ESTEVEZ BRASA, 1981). 
1.2.3. Fontes de enlace entre a lei, a doutrina e a jurisprudência:

As fontes de ligação são utilizadas para buscar a compreensão das fontes primárias.

a) Fatwa

A fatwa é a opinião ou parecer do mufti. Uma de suas principais funções é fundamentar as sentenças dos qadi. Ela busca a reinterpretação de uma regra de direito, trazendo resposta a uma dúvida ou pergunta. Não é uma sentença, mas um parecer do tipo consultivo e aclarativo que poderá embasar uma decisão (ESTEVEZ BRASA, 1981).

b) Tafsir

A tafsir é a explicação e compreensão da lei divina. Ela é feita pelos muqallidin. Quando um texto interpreta de forma diferente uma situação disciplinada por outro texto, encontrados ambos nas fontes primárias ou ambos nas secundárias, cria-se uma contradição. Os tafsir servem para conciliar estas contradições com a única limitação de não aplicar distintos temperamentos a um determinado assunto. Ou seja, se aplicarem uma postura de uma escola em um determinado ponto, a esta escola deverão seguir na resolução desse conflito. Esta forma de explicação e compreensão permite obter regras de direito e conservar a plenitude e pureza dos textos sagrados (ESTEVEZ BRASA, 1981).

\section{c) Istahsan}

A istahsan é a equidade. Ela é obtida por meio da experiência do mudjtahidin. Se não houver uma solução clara para o caso concreto, este é chamado para oferecer uma solução com base na equidade. Ela tem primazia mesmo frente aos qyyas, e é uma importante fonte de direito (ESTEVEZ BRASA, 1981). 
d) Maslaha

A maslaha é o bem público. Sua utilização se dá quando em um caso concreto há colidência entre um interesse público e um interesse privado. Neste caso o mudjatahidin é chamado a oferecer uma solução que respeite o interesse e o bem público (ESTEVEZ BRASA, 1981).

O quadro abaixo, elaborado por Estevez Brasa (1981) resume, de uma maneira diversa da apresentada no presente trabalho, as fontes do direito muçulmano, não trazendo os elementos de ligação:

\begin{tabular}{|l|l|c|}
\hline $\begin{array}{l}1 \text { - Fontes-fontes (vertentes) } \\
\text { originais, causais }\end{array}$ & Forma e fundo do direito & $\begin{array}{c}\text { Qoran e } \\
\text { Sunna } \\
\text { Shari’a }\end{array}$ \\
\hline $\begin{array}{l}2 \text { - Fontes-causas (formadas) } \\
\text { complementares, conseqüentes }\end{array}$ & Intuição e razão do direito & $\begin{array}{c}\text { Ijma } \\
\text { Kiyas }\end{array}$ \\
\hline $\begin{array}{l}3 \text { - Fontes-afluentes (sedimentadas) } \\
\text { elaboradas ou espontâneas }\end{array}$ & Vulgarização e cientifisação do direito & $\begin{array}{c}\text { Urf } \\
\text { Amal }\end{array}$ \\
\hline
\end{tabular}

Figura 1: Fontes do Direito Muçulmano elaborado com base em ESTEVEZ BRASA, 1981, p. 149.

Outra maneira de representar as fontes do direito muçulmano é, comparando-as com as fontes do civil law, apresentar quais podem ser comparadas a leis, doutrina, jurisprudência e costume:

\begin{tabular}{|l|l|}
\hline Lei & $\begin{array}{l}\text { Shari'a e por extensão Ijma } \\
\text { Kanun como fonte não revelada }\end{array}$ \\
\hline Doutrina & Fatwa, kiyas, tafsir, ijtihad \\
\hline Jurisprudência & Amal, idjitahad \\
\hline Costume & Urf \\
\hline
\end{tabular}

Figura 2: Fontes do Direito Muçulmano comparados ao Civil Law elaborado com base em ESTEVEZ BRASA, 1981, p. 172.

Contudo, optou-se pela sistematização em fontes primárias, fontes secundárias e elementos de ligação, por entender-se que desta maneira se respeita a hierarquia que o direito muçulmano estabelece para estas fontes. Esta concepção resume-se no quadro abaixo: 


\begin{tabular}{|c|c|}
\hline Fontes Primárias & $\begin{array}{c}\text { Qoran e Sunna } \\
\quad=\text { Shari'a }\end{array}$ \\
\hline Fontes Secundárias & $\begin{array}{c}\text { Ijma } \\
\text { Qyyas } \\
\text { Urf } \\
\text { Amal } \\
\text { Kanun } \\
\text { Ijtihad }\end{array}$ \\
\hline Elementos de Ligação & $\begin{array}{c}\text { Fatwa } \\
\text { Tafsir } \\
\text { Istahsan } \\
\text { Maslaha }\end{array}$ \\
\hline
\end{tabular}

Em suma, são estas as fontes que guiam a compreensão de todo o direito muçulmano e, mediante a sua utilização, vem este direito procurando se adaptar às novas realidades que o contato com outros ordenamentos jurídicos vem criando dentro e ao entorno da sociedade muçulmana.

\section{O Direito Real}

Na religião muçulmana o usul é o tronco do direito. Dentro deste tronco existem os vários ramos, que são os furu. Um destes ramos é o umamalat, que é o ramo do direito entre os homens, ou seja, o direito privado. Outro ramo é o ibadat, que são os direitos divinos, o que poderia ser chamado comparativamente de direito público. É dentro deste último ramo que se encontra o direito pessoal e o direito real (ESTEVEZ BRASA, 1981). O presente capítulo se restringe aos direitos reais. 
Este capítulo se divide em uma parte geral e uma parte mais específica. A primeira trata da posse e da propriedade, abordando o conceito desses institutos, sua extensão, peculiaridades e principais características. A segunda parte trata de alguns institutos específicos do direito muçulmano. Não que institutos semelhantes não sejam conhecidos em outros sistemas jurídicos. Mas o que busca abordar é a característica desses institutos e uma breve comparação destes com semelhantes do direito brasileiro. Especificamente serão tratados do awqaf, da co-propriedade e das utilidades e garantias da posse.

\subsection{Posse e propriedade}

Um preceito que fica muito claro na doutrina consultada é que o sujeito de direito muçulmano não é dono de tudo que é criado, é um administrador dos bens de Deus. E a propriedade/administração dos bens advém diretamente do merecimento em deter esta possibilidade. Na relação do homem com as coisas, a dádiva divina exerce o papel de protagonista, o homem é apenas um coadjuvante. E esta concepção permeia todo o direito (ESTEVEZ BRASA, 1985).

Contudo, em que pese esta concepção o princípio erga omnes existe de forma bastante clara no Islan, como uma obrigação passiva universal (ESTEVEZ BRASA, 1985). Outro ponto importante a ressaltar é que subjetividade na relação jurídica torna menos precisa a divisão entre direitos reais e pessoais. Um exemplo disso é que o direito de propriedade, em que pese sua importância, não aparece delimitado na normalização muçulmana, mas espalhado, entre outros institutos e tratando de situações específicas ligadas a estes. Não há uma parte, um capítulo, um direito especial de propriedade, há a regulação de situações fáticas nas quais está envolvido inclusive o direito real (SCHACHT, 1975).

No direito brasileiro, a teoria dominante é a de que a propriedade é inerente à natureza humana. A propriedade não deriva da lei ou do Estado, mas de um direito natural que antecede a todos eles (GOMES, 2000). 
Assim como a religião domina fundamentalmente em matéria de instituição familiar, são principalmente as circunstancias políticas, sociais e econômicas as que incidem no desenvolvimento do direito de propriedade. Em virtude da origem tribal e nômade, a apropriação e as formas coletivas de propriedade da terra têm uma ampla recepção. Os povos árabes conheciam a propriedade individual do que possuíam: armas, roupas, cavalos. Mas as terras conquistadas pertencem desde suas origens à comunidade muçulmana. E a idéia de propriedade, ressalta-se mais uma vez, está diretamente ligada com o conceito de merecimento, de sua obtenção mediante o trabalho (ESTEVEZ BRASA, 1985).

\subsubsection{Propriedade}

No direito muçulmano existem duas formas de propriedade as terras de kharadj e as terras de awqaf em razão da conquista islâmica.

As terras kharadj são como um arrendamento a um proprietário superior, que é Deus representado pela Comunidade Muçulmana. O homem é proprietário originário, ou por compra e venda, da terra, mas precisa pagar uma contribuição territorial para manter esta terra, que é o kharadj (ESTEVEZ BRASA, 1985).

As terras de awqaf são terras conquistadas em razão de guerra e divididas entre os vencedores. Mediante a instituição de um awqaf, eles podem usufruir da terra, por meio do pagamento de um tributo à Comunidade Muçulmana (ESTEVEZ BRASA, 1985).

\section{a) Formas de aquisição da propriedade}

No direito muçulmano são duas as formas de aquisição da propriedade: a originária e a derivada. A originária ocorre quando há a primeira ocupação de um lugar, que é o istila', e este não tem dono anterior. A derivada se dá pela transferência da propriedade por meio da transferência da posse, que é a venda. Ela também pode se dar com a transferência da propriedade derivada, que consistem em transações com esses direitos de propriedade que no direito bra- 
sileiro são compreendidos como direito sobre coisa alheia. E ainda a promessa de transferência, onde a transferência da propriedade só ocorre quando se realizar o contrato (SCHACHT, 1975).

\section{b) Categorias de bens e direitos}

No direito brasileiro considera-se direito sobre a propriedade o jus utendi, o jus fruendi, o jus abutendi e o revindicatio, ou seja, o direito de usar, gozar, dispor e reaver o bem de quem injustamente o tenha usurpado, conforme artigo 1228, do Código Civil Brasileiro (CCB).

No direito muçulmano se reconhece sobre a propriedade o milk e o manafi. O milk é o direito de propriedade, a faculdade de domínio e disposição sobre o bem. É o direito sobre as armas, animais, casas, águas para irrigação, pois a terra era apropriada segundo convinha ao exercício do nomadismo. O manafi é a utilidade do bem (ESTEVEZ BRASA, 1985).

Sobre a propriedade pode haver a shirkat, que é a sociedade sobre o bem e a shuf'a, que é o condomínio. O bem também pode ser vendido pela bai' que é a troca de propriedade por propriedade como consentimento mútuo das partes (ESTEVEZ BRASA, 1985) O mal são as riquezas e os bens que constituem o patrimônio das pessoas, os bens que estão no comércio. Mas não podem ser objeto de propriedade privada os bens de uso comum e indispensável para a vida: o ar, a luz e o fogo (SCHACHT, 1975).

\subsubsection{Extensão do direito de propriedade}

A extensão do direito de propriedade diz respeito à superfície, subsolo, águas, tesouro e jazidas minerais.

a) Propriedade da superfície

A propriedade do solo implica na propriedade da superfície do solo. O proprietário pode se opor às construções limítrofes que invadam seu terreno, bem como que as ramas das árvores vizinhas 
caiam sobre ele. Também pode elevar sobre seu terreno qualquer tipo de construção e até a altura que desejar (ESTEVEZ BRASA, 1985).

\section{b) Propriedade do subsolo}

O proprietário do solo também o é do subsolo, podendo utilizar seu terreno da forma que quiser, cavar poços e construir depósitos no subsolo. Contudo seu direito é limitado pelo dano que possa causar a seu vizinho (ESTEVEZ BRASA, 1985).

No direito brasileiro, conforme artigo 1229 do CCB a propriedade do solo abrange a do subsolo, em profundidade útil ao seu exercício, não podendo, entretanto o proprietário se opor a atividades que sejam realizadas, por terceiros, a uma profundidade tal que não tenha ele interesse legítimo em impedi-la.

\section{c) Regime de águas}

A água é muito importante no direito muçulmano. As águas de vertentes, de rios e de lagos, não podem ser objeto de concessão em hipótese alguma. Só cabe a regulamentação de seu uso pelo soberano, já que todos têm direito a sua utilização para as necessidades pessoais, de seus animais e para a irrigação da terra, que é o direito de shirb (ESTEVEZ BRASA, 1985).

Os muçulmanos têm participação por igual em três coisas: água, erva, fogo. Todavia, se um não-muçulmano chega à água, antes de havê-lo feito um muçulmano, esta lhe pertence. É proibida a venda do excesso de água, pois a água é de propriedade comum, independente do terreno onde esteja. Quem cava um poço em sua propriedade também não é proprietário exclusivo de suas águas. Este apenas terá direito à indenização caso a forma de utilização das águas cause prejuízo ao proprietário da terra (ESTEVEZ BRASA, 1985).

Há uma exceção para utilização no caso de pequenos rios, cujo direito e uso se limita quanto ao direito de shirb (irrigação) aos ribeirinhos de forma exclusiva. Ou seja, se um muçulmano tem um pequeno rio que cruza sua propriedade, apenas ele tem o direito de utilizar a água deste rio para a irrigação, podendo os outros usufruir 
desta água para uso pessoal, bem como para seus animais. Em todo o caso prevalece sempre o direito da comunidade em relação ao direito individual (ESTEVEZ BRASA, 1985).

\section{d) Regime de tesouro}

O tesouro é um objeto sem dono conhecido, enterrado em um imóvel. Ele terá diferentes tratamentos dependendo de sua origem. Estando em terra pública um quinto do tesouro vai para a comunidade e o restante para o descobridor. Estando em terra particular vai para o proprietário da terra. Sendo de origem muçulmana - não pertence a ninguém durante um período de tempo estipulado, ficando o descobridor como depositário do tesouro. Se transcorrido esse período ninguém aparecer, ele pode ficar com o tesouro. Mas se a pessoa aparecer posteriormente, ele terá que indenizar (ESTEVEZ BRASA, 1985).

No direito brasileiro, segundo o art. 1264 e seguintes do CCB, o tesouro é um depósito antigo de coisas preciosas, oculto e cujo dono não haja memória. Se encontrado em terreno alheio, divide-se entre o proprietário e o quem achar o tesouro. Mas se achado pelo dono do terreno, ou por pesquisa que ordenou ou por terceiro não autorizado, pertence a ao proprietário do terreno. No direito brasileiro é crime se apropriar da quota a que tem direito o proprietário do prédio, conforme o art. 169, do Código Penal Brasileiro.

\section{e) Jazidas minerais}

A propriedade das jazidas minerais pode ser tratada de três maneiras distintas, conforme as várias escolas do direito. Segundo a primeira interpretação, é proprietário o dono do solo, com obrigação de pagar um tributo ao Estado. Conforme a segunda, a jazida sempre é de domínio público. Na abordagem da terceira, estando na superfície a jazida é da Comunidade Muçulmana. Para a escola Malekita prevalece a autoridade estatal e a necessidade de concessão para explorar a jazida (ESTEVEZ BRASA, 1985). 
Vale ressaltar que se trata de instigante tema dentro do direito muçulmano, posto que muitos dos estados muçulmanos se encontram no oriente médio, região de constantes disputas por um dos minérios mais valorizados da atualidade: o petróleo.

No direito brasileiro, segundo o artigo 1230 do CCB, a propriedade do solo não abrange as jazidas, minas e demais recursos minerais. Estes recursos naturais devem ser objeto de concessão pela União para serem explorados.

\subsubsection{Posse}

No direito muçulmano a posse é, acima de tudo, o melhor meio probatório do direito de propriedade, ao qual terceiros não podem se opor.

As formas de posse no direito muçulmano são as seguintes:

I - yah - é o fato possessório e consiste em ter a posse do imóvel. Para utilizá-la se exige o uso da regra conhecida como istishab. Esta regra, que presume ser possuidor o que está em posse do bem, exige uma prova pertinente da posse/propriedade antes de turbar a posse do outro (ESTEVEZ BRASA, 1985).

II - hawz - é a posse qualificada. Para ter este tipo de posse, deve-se estar no imóvel por no mínimo dez a doze meses, dependendo do rito adotado. Deve-se ter fama de proprietário, ter a posse pacífica durante o ano todo. Este tipo de posse é válido se o proprietário anterior era desconhecido (ESTEVEZ BRASA, 1985).

Mas se o proprietário anterior era conhecido, há dois tipos de posse:

III - hiyaza - é a posse larga. Para esta forma deve-se estar de posse do imóvel por dez anos, além de ter fama de proprietário e ter a posse de forma pacífica (ESTEVEZ BRASA, 1985).

IV - posse larguíssima. Esta é a posse durante cinqüenta anos (ESTEVEZ BRASA, 1985).

Estas formas de posse valem como prova do direito de propriedade do possuidor, se ele se encontra ocupando a terra na qualidade 
de dono. Mas se o possuidor entrou na terra a título de usuário ou de empréstimo, nem a posse larga purga o vício, pois em sua entrada ele não ocupava a terra na qualidade de dono (ESTEVEZ BRASA, 1985).

O quadro abaixo esclarece a forma de garantir-se a posse:

\begin{tabular}{|l|c|c|}
\hline \multirow{2}{*}{ Possuidor atual } & Proprietário anterior & $\begin{array}{c}\text { Desconhecido: } \\
\text { hawz e juramento }\end{array}$ \\
\cline { 3 - 3 } & & Conhecido: hiyaza \\
\cline { 3 - 3 } & \multirow{2}{*}{ Título } & Desconhecido: Hawz \\
\cline { 3 - 3 } & & Conhecido e vicioso: hiyaza \\
& não desfaz o vício \\
\hline
\end{tabular}

Figura 4: Formas de garantir a posse. Elaborado com base em: ESTEVEZ BRASA, p. 257, 1981.

Se o possuidor atual for questionado em sua posse quatro possibilidades podem apresentar-se. Se o proprietário anterior era desconhecido, ele tendo uma posse hawz e fazendo o juramento de que é dono lhe garante a posse. Se o proprietário anterior era conhecido, apenas tento uma posse hiyaza lhe garante a permanência na posse. Se ele possuir um título que comprove sua posse ou propriedade, e sendo desconhecido o proprietário anterior, uma posse hawz lhe garante a permanência. Mas se o proprietário anterior era conhecido e ele não entrou de na posse como dono, embora tenha título, nem a posse tipo hiyaza o permite ficar no imóvel (ESTEVEZ BRASA, 1985).

\section{a) Prescrição}

No direito brasileiro há, dentre outras, duas formas de prescrição: a prescrição aquisitiva / usucapião, que confere um título de direito real; e a prescrição extintiva/ liberatória, que põe fim a uma obrigação.

No Islan estas formas de prescrição não são aceitas desta forma pois: é uma profanação da ordem estabelecida pelo criador tirar a propriedade de suas terras do verdadeiro proprietário; e o Qoran manda todos pagarem suas dívidas (ESTEVEZ BRASA, 1985). 
A posse não é uma forma de adquirir o usucapião, como no direito brasileiro, mas um meio para repelir uma ação reivindicatória impetrada pelo verdadeiro ou suposto proprietário da terra. Todavia nenhuma modalidade de posse é válida quando se tratar de bens que sejam de domínio público e de bens que sejam os awqaf (ESTEVEZ BRASA, 1985).

No direito muçulmano a prescrição da posse não corre contra incapazes, mesmo que este tenha um tutor. Também não ocorre contra ausentes que estejam a uma certa distância de forma que não possam atuar, e não ocorre quando os donos estejam submetidos à coação, seja ela força ou terror. A demanda judicial interrompe a prescrição da posse. O prazo de duração da prescrição de uma posse varia segundo o tipo de bem, a relação pessoal entre as pessoas e se trata de ato entre vivos ou causa da sucessão. Por exemplo, entre estranhos o tempo de prescrição é menor que entre parentes. Para bens móveis o prazo é muito mais reduzido. Também se pode somar o tempo do antigo possuidor com o novo, bem como na sucessão (ESTEVEZ BRASA, 1985).

A posse não significa com respeito ao proprietário a perda de sua propriedade, senão o impedimento para intentar a reivindicação. Ele continua sendo proprietário, mas não pode tirar da posse quem a tenha pelo tempo estipulado na lei. A posse não é um direito em si, mas uma exceção dentro de uma ação reivindicatória. No direito muçulmano as características e conseqüências da posse autorizam sua qualificação como direito, e até como um direito real. Ela é um fato que gera direito (ESTEVEZ BRASA, 1985).

Há os Hakk al yah - direitos derivados da posse e a Mik al yah - propriedade em virtude da posse. Na teoria se distingue a posse da propriedade, mas na prática pode-se usar uma ação reivindicatória para garantir a posse de um ano, embora exista a ação de defesa possessória. Isso por que quem demanda acaba por defender um direito de propriedade (ESTEVEZ BRASA, 1985). 
b) Frutos e melhorias

No direito muçulmano o possuidor sempre fica com os frutos e melhorias. Se as melhorias passarem do preço da terra, o possuidor de boa fé fica com a terra. Mas se o possuidor for de má fé o proprietário só deve pagar as melhorias. Se não quiser pagar, o proprietário de má fé pode ficar no imóvel pagando pelo preço dele (ESTEVEZ BRASA, 1985).

No direito brasileiro, segundo o artigo 1232, CC, os frutos do imóvel pertencem ao seu proprietário. Conforme artigo 1256, $\mathrm{CC}$, aquele que promove melhorias de má fé perde em proveito do proprietário estas melhorias, mas se o fez de boa fé, terá direito à indenização. Se a melhoria exceder o valor do imóvel, e esta foi feita de boa fé, que a executou poderá ficar com o imóvel, desde que pago o preço justo.

\section{Institutos Muçulmanos do direito de propriedade}

\subsection{Awqaf}

O instituto do awqaf, no singular waqf é uma espécie de doação de um usufruto de um bem imóvel com um fim piedoso ou benéfico, ou ainda de utilidade geral. Este bem permanece fora do comércio imobiliário e do exercício da autoridade pública. Esta doação é diferente da caridade pois a 'illa do awqaf, ou seja, a razão do direito, é diferente (ESTEVEZ BRASA, 1985).

Mediante a instituição do waqf pode-se: retificar ou alterar a ordem das sucessões; dispor da cota de bens que se deseje sem atender às prescrições em matéria sucessória; proteger os bens contra os requerimentos do Estado; assegurar uma situação patrimonial privilegiada de uma família tradicionalmente poderosa. O awqaf também pode ser uma arma eficaz para proteger o patrimônio nacional em países com graves problemas de desenvolvimento contra 
a voracidade dos agentes colonialistas. Por outro lado ele pode representar uma sobrevivência retardatária de antigos privilégios de clãs ou grupos familiares (ESTEVEZ BRASA, 1985).

\section{a) Instituição do awqaf}

Para instituir um waqf precisa-se respeitar a uma série de requisitos. O primeiro deles é a capacidade. Para sua instituição o constituinte deve ser maior de idade, livre, muçulmano, não pode ser doente mental, e não pode estar na iminência ou em estado de falência. O segundo é a forma. A instituição deve se dar mediante o consentimento das duas partes, o constituinte e a instituição beneficiada, na presença de testemunhas e do qadi, para efeitos notariais. Pode se instituir o waqf, no caso de doações, com um termo ou uma condição (ESTEVEZ BRASA, 1985).

Outras circunstâncias devem ser apontadas na instituição de um waqf. Por exemplo, quem constitui um waqf só mantém para si a nu propriedade. Desvincula-se totalmente do gozo do bem. Porém tem-se admitido que o constituinte possa designar a si mesmo em primeiro lugar na ordem dos beneficiários do waqf. Por outro lado, o bem deve pertencer em plena propriedade ao constituinte, ou seja, é indispensável que quem constitua o waqf possa dispor livremente do bem. Além disso, ele pode ser constituído sobre todo o bem imóvel. Em alguns casos se aceita a constituição sobre bem móvel, mas isso desvirtua o instituto. Os acessórios de um imóvel constituído em waqf ficam afetados a esse mesmo fim. E pode-se entregar a totalidade do patrimônio até em detrimento dos parentes mais próximos, mas não se aceita sua constituição sobre bens futuros (ESTEVEZ BRASA, 1985).

Outra questão que permeia o waqf é como distribuir os bens, no caso da instituição que tenha como beneficiário intermediário a família. Primeiramente deve-se respeitar o que foi estipulado no waqf. Mas quando a intenção não é clara, sempre se trata de atender às filhas mulheres e suprir as suas necessidades (ESTEVEZ BRASA, 1985). 
b) Tipos de awaqf

Há dois tipos de awqaf, o privado e o público. O awqaf privado se dá quando há um beneficiário intermediário antes que o usufruto passe definitivamente para o seu beneficiário final. O público se dá quando o beneficiário é imediatamente uma instituição de caridade (ESTEVEZ BRASA, 1985).

Com relação à sua revogação, uma teoria entende que, se constituído em vida por seu fundador, poderia haver uma liberdade para revogá-lo, salvo se o juiz tivesse estabelecido sua perpetuidade. Outra teoria mais aceita é a de que o constituinte se desposa de seus bens e o desdobramento em propriedade e usufruto se produz correspondendo a primeira a Deus e a segunda aos beneficiários. Alguns aceitam a possibilidade de revogar a instituição, mediante cláusula. Para outros esta cláusula significa a nulidade do awqaf, e outros ainda consideram a cláusula como não escrita (ESTEVEZ BRASA, 1985).

\section{c) Beneficiários}

Geralmente os beneficiários definitivos são instituições de caridade e os beneficiários intermediários são familiares do constituinte. Se estes não cuidarem do bem, o beneficiário definitivo pode acioná-los, e o qadi pode determinar uma intervenção (ESTEVEZ BRASA, 1985).

Os beneficiários não podem alterar a substância nem as qualidades do bem. Se ele é destinado à pecuária, não pode ser utilizado para construir casas. Alguns ritos admitem ser instituída cláusula determinando que se os beneficiários se encontrarem em pobreza extrema, o bem pode ser vendido para que eles possam sobreviver deste. Também admite cessão dos direitos por expropriação por causa de utilidade pública, ou, se bens móveis, por se tornarem inúteis ou inadequados. Salvo isso não se pode proceder a venda. Não corre prescrição contra os beneficiários futuros (ESTEVEZ BRASA, 1985). 
d) Administração

A administração do waqf é feita pelo mukaddam, que é designado pelo constituinte ou pelo qadi. Ele é um representante do waqf e não dos beneficiários, e pelo waqf deve zelar. O beneficiário definitivo também pode ter um representante que zele pelos seus direitos (ESTEVEZ BRASA, 1985).

Há limitações para a administração. Por exemplo, o mukaddam não pode contratar algo sobre o bem a longo prazo, pois esta contratação pode resultar em perda da posse do bem, desgaste do bem, e acabar por desvirtuar o instituto e prejudicar os beneficiários. Por fim, se o fim para o qual o bem foi destinado não se cumpre, pode-se aplicar o bem a uma outra instituição afim (ESTEVEZ BRASA, 1985).

\section{e) Controle oficial}

Nos países muçulmanos há uma administração geral dos awqaf, onde estes devem ser registrados. Contudo, sua falta de registro não o anula (ESTEVEZ BRASA, 1985).

Por outro lado, como a imobilização dos bens resultante dos awqaf pode trazer conseqüências desfavoráveis para o mercado imobiliário e a economia de um país, em alguns países há um estímulo à mobilização dos imóveis afetados. Além disso, há dois meios legais que podem ser aplicados para promover esta desmobilização: o bai 'al manafa, que é a venda do desfrute do bem; e o bai 'al hawa', que é a venda do ar (ESTEVEZ BRASA, 1985).

\section{f) Bai'al manafa}

A venda do desfrute do bem significa que pode ser feita a alienação do usufruto do bem de forma perpétua a terceiro, de modo que os beneficiários não disponham do usufruto, mas da renda proveniente dele. Isso pode desvirtuar o instituto, pois a parte mais importante do benefício, o usufruto o bem, fica para o cessionário. No caso da exploração da terra, por exemplo, isso pode significar o empobrecimento deste ou até muitas vezes a perda da posse da terra (ESTEVEZ BRASA, 1985). 
g) Bai' al hawa'

A venda do ar permite que em terras de awqaf possam se realizar construções mediante o pagamento de uma renda pelo adquirente. Cria-se assim uma coexistência das propriedades - a do beneficiário e a do adquirente do ar - mantendo-se o pagamento de uma renda determinada. Isso também pode desvirtuar o instituto por que com o tempo o patrimônio se deteriora podendo vir a diminuir a renda (ESTEVEZ BRASA, 1985).

\section{h) Outras considerações}

Este instituto pode ser comparado ao Trust do direito inglês e ao fideicomisso do direito brasileiro. No caso do fideicomisso, ele pode ser equiparado por como o awqaf por resultar de uma disposição pela qual o fideicomitente institui herdeiros ou legatários, impondo a um deles, o fiduciário, a obrigação de, sob termo ou condição, transmitir a outro, o fideicomissário, a herança ou legado (GOMES, 2000). Assim como o beneficiário intermediário tem a fruição da coisa, e depois do termo ou condição, que pode ser a sua morte, ele passa esta fruição ao beneficiário seguinte, que pode ser outro intermediário ou o final. E em casa período o beneficiário ou legatário, é pleno de direitos sobre a fruição ou a propriedade, passando esta plenitude para o beneficiário ou legatário seguinte. No Trust a semelhança se encontra em o instituidor elege um trustee para administrar um conjunto de bens, assim como o mukaddam no awqaf, e repassar aos beneficiários instituídos a fruição destes bens, e a um termo ou condição, passar a fruição aos beneficiários seguintes.

Há algumas contradições neste instituto. Uma delas é os awqaf adotarem uma personalidade jurídica num sistema que não reconhece a personalidade ficta. Também há o problema de awqaf ser utilizado para: o nome do instituto, o ato constitutivo e a coisa afetada (ESTEVEZ BRASA, 1985).

Outra contradição é o instituto não ter surgido de forma precisa no Qoran nem na Sunna, nem mesmo de uma ijma. Mas uma vez aceita, ela é praticada como se fosse lei primária. A explicação poderia 
ser encontrada no profundo sentido caritativo do ideal islâmico. E sua origem pode ser regatada em um hadith que descreve quando o profeta aconselha Omar a imobilizar algumas terras que deviam ser consagradas a Deus. Mas não há nada preciso com relação ao seu surgimento (ESTEVEZ BRASA, 1985).

Se de um lado permite a manutenção de orfanatos e hospitais, de outro permite que grupos sociais parasitários ou parasitismo de bens que influem desfavoravelmente na vida social, política e econômica de um país.

\subsection{Co-propriedade: condomínio}

Para se falar de co-propriedade e condomínio, é necessário ressaltar que há um grande interesse do mundo muçulmano pela indivisão dos bens, por ser fonte de união entre as famílias, e resultar em melhor desenvolvimento econômico aos participantes da comunidade. Isso não quer dizer que não exista a repartição, pois cada condômino pode solicitá-la e só se não houver acordo entre as partes haverá a intervenção do qadi. Mas o qadi sempre procurará manter indivisa a propriedade (ESTEVEZ BRASA, 1985).

Se um dos condôminos vende sua parte do bem ou o todo, os demais condôminos têm o direito de requerer que o qadi declare a retratação da venda, mediante os seguintes institutos: a shuf'a, a safka e o damm.

a) Shuf'a

A shuf'a é o direito de preferência que o co-proprietário pode exercer colocando-se entre o comprador e o condomínio e pagando os gastos que o comprador teve para adquirir a parte da propriedade (ESTEVEZ BRASA, 1985).

Isso é possível por que se entende que a introdução de um estranho pode gerar situações inconvenientes dentro do condomínio e da co-propriedade. Também se justifica para evitar o parcelamento excessivo das terras e um possível empobrecimento de todos que 
ficarão cada qual com uma parcela reduzida da propriedade. Trata-se de uma expropriação por interesse familiar ou econômico e social (ESTEVEZ BRASA, 1985).

Este direito é reconhecido apenas às pessoas que tenham interesses vinculados com a propriedade que se venda. Este pode ser exercido por co-proprietários ou por vizinhos, ou pessoas que tenham direito de servidão (ESTEVEZ BRASA, 1985).

Para exercer este direito, algumas condições devem ser respeitadas: o qadi intervirá apenas se as partes não entrarem em acordo; quem vai exercer a shuf'a deve se manifestar dentro de um determinado período, que varia de dois meses até um ano, para que se produzam os efeitos; este o prazo corre contra menores que tenham tutores; se morre quem tem o direto à shuf'a antes de cumprir o prazo de exercê-la, seus sucessores podem fazê-lo; quem for exercer o direito deve o fazer na totalidade da parte vendida, pois a principal justificativa é não ter estranhos na co-propriedade; ela exige o pagamento imediato ao comprador com o preço mais os gastos, aceitando-se um prazo de três dias para o pagamento integral; a shuf'a só pode exercer-se contra um comprador a título oneroso (ESTEVEZ BRASA, 1985).

Em todos os casos deve se considerar o interesse familiar e social, o sentido de justiça com relação aos direitos adquiridos, direitos de menores e incapacitados (ESTEVEZ BRASA, 1985).

No direito brasileiro também há o direito de preferência em favor dos demais condôminos. Ele deve ser requerido no prazo de 180 dias da ciência inequívoca da venda, pagando-se o preço pago pelo comprador, sob pena de decadência, conforme artigo 504, CC. Há ainda preferência entre os condôminos, o tendo o que tiver o maior quinhão, o que não há no direito muçulmano.

Efeitos:

Os principais efeitos dizem respeito a frutos, construções e indenização. Se o comprador perceber frutos durante o período em que estiver com o bem, não precisa reintegrá-los. Se ele tiver construído, não precisa retornar ao estado anterior e deve ser recompensado pelos gastos. O mesmo ocorre se sofrer danos. Quem exerce a shuf'a não pode reclamar indenização alguma (ESTEVEZ BRASA, 1985). 
É importante ressaltar que se considera havida a primeira e a segunda venda, reconhecendo-se os efeitos destas. Assim com relação ao direito de evicção não pode quem exerce a shuf'a exigi-la do primeiro vendedor, mas do segundo. Isso por que se trata de uma venda forçada e não de uma resolução da primeira venda (ESTEVEZ BRASA, 1985).

Limites ao instituto:

Pode-se limitar a utilização deste instituto mediante as seguintes formas de venda: a venda por quantidade desconhecida, na qual o vendedor paga um valor que deve ser completado com outro valor que não é declarado, e esta parte se entrega aos pobres. Assim é impossível pagar o preço certo para exercer a prioridade e a shuf'a acaba impedida; o vendedor reserva para si uma parte do bem que vendia. Desta maneira os demais proprietários não poderão despojá-lo de seu próprio direito e a shuf'a não se consuma para o comprador, pois ela só se aplica na integralidade do quinhão ideal que pertencer ao primeiro vendedor. Contudo, atualmente há muitas restrições para o exercício do instituto, por resultar em uma grande incerteza jurídica (ESTEVEZ BRASA, 1985).

\section{b) Safka e damm}

A safka se dá com a venda de uma coisa alheia que se produz quando um co-proprietário vende a integralidade do bem que tem em comum com os demais, ou seja, cede os seus direitos e os dos outros também. Em regra é proibida, sendo permitida quando os condôminos estão neste estado por causas comuns: herança e venda. Assim, se todos adquirem de forma comum a coisa indivisa, cada um está autorizado a vendê-la. Esta possibilidade não é permitida no direito brasileiro, sem o consentimento dos outros condôminos (ESTEVEZ BRASA, 1985).

Mas se os demais co-proprietários não aceitam a decisão, eles podem exercer o damm, que resulta em expropriar do adquirente o bem, reembolsando-o dos gastos, e repartir entre os demais a parte do vendedor. Neste caso o adquirente não tem direito aos frutos que possa haver percebido (ESTEVEZ BRASA, 1985). 


\subsection{Utilidades e garantias}

No presente trabalho as utilidades e garantias do direito muçulmano, que serão estudadas, são o usufruto, a servidão, a retenção e os privilégios.

a) Usufruto, uso e habitação: direito ao gozo de uma coisa

No direito muçulmano o usufruto não termina pelo não uso, pois não se aceita a perda de um direito pelo simples transcurso do tempo (ESTEVEZ BRASA, 1985). Ele é considerado uma espécie de propriedade e não, como no direito brasileiro, um direito sobre coisa alheia.

As obrigações do usufrutuário são suportar os gastos para a manutenção do bem, os próprios da coisa e o pagamento dos impostos (ESTEVEZ BRASA, 1985). No direito brasileiro o usufrutuário não é obrigado a pagar as deteriorações resultantes do exercício regular do usufruto, conforme artigo 1402, CCB. Mas ele deve conservar o bem no estado em que o recebeu e arcar com as prestações e tributos devidos pela posse ou rendimento da coisa usufruída.

No direito muçulmano, em alguns casos restritos, é possível dispor de seu direito de usufrutuário e cedê-lo (ESTEVEZ BRASA, 1985). No direito brasileiro não se pode alienar este direito, mas ceder o seu exercício, a título gratuito ou oneroso, conforme o artigo 1393, CCB.

Para o usufrutuário arrendar há terra há limitação, pois o nu proprietário pode enfrentar problemas de longas locações da terra, inclusive com a perda da posse desta. Também não se pode mudar o destino do bem (ESTEVEZ BRASA, 1985).

No direito muçulmano o nu proprietário não tem outra obrigação que entregar a coisa para o usufrutuário (ESTEVEZ BRASA, 1985). No direito brasileiro o proprietário tem a obrigação de fazer as reparações extraordinárias e as que não forem de custo módicos, sendo entendidas como as que passarem de dois terços do rendimento líquido de um ano, conforme artigo 1404, CCB. 
b) Servidões: obrigação de vizinhança

No caso das servidões deve imperar a necessidade de respeitar os direitos de cada um, causando o menor prejuízo possível. Em regra as servidões são instituídas por lei, mas também podem ser convencionadas (ESTEVEZ BRASA, 1985). No direito brasileiro a servidão predial é constituída de forma convencional, conforme artigo 1378, CCB, mediante acordo entre as partes, ou em juízo. E pode-se inclusive pedir usucapião desta decorridos 10 anos com título e 20 sem título, conforme artigo 1379, CCB. Mas o dono do prédio serviente não poderá embaraçar o exercício legítimo da servidão, conforme artigo 1383, CCB. E ela deve ser registrada no registro de imóveis.

Há vários tipos de servidões no direito muçulmano: o direito do vizinho entrar na propriedade do outro em caso de recolher frutos das árvores de sua propriedade; o direito do proprietário de uma árvore plantada em um terreno alheio à propriedade da terra circulante necessária para a nutrição da planta; o proprietário que não tem saída para uma via pública e passa pela propriedade de outros, devendo efetuar o trajeto mais direito e menos danoso (ESTEVEZ BRASA, 1985). No direito brasileiro, conforme artigo 1285, CCB, assegura-se ao proprietário do prédio que se achar encravado, sem acesso à via pública, constranger o vizinho a dar passagem, mas mediante pagamento de indenização.

Há ainda no direito muçulmano a passagem para boiada, cuidando para não causar dano aos frutos das colheitas das terras que atravessam. E com relação à água, o vizinho de baixo não tem a obrigação de receber as águas que descem do vizinho de cima (ESTEVEZ BRASA, 1985).

No direito brasileiro o não uso por dez anos extingue a servidão, conforme artigo 1389, CCB. No direito muçulmano isso não parece ser possível, pois sempre há um direito de utilizar-se da servidão caso esta seja necessária (ESTEVEZ BRASA, 1985). 
c) Direito de retenção

A concepção muçulmana é bastante mais rígida quando às limitações que opõe ao exercício do direito de retenção por quem o pretende. Pode reter o bem quem o detém e é credor do proprietário deste, tendo esta faculdade de retê-lo até que o débito seja pago. Este direito é reconhecido: para o comprador sujeito do direito de shuf'a; para o vendedor e comprador que não tenha pago o preço da coisa, ou que a venda tenha resultado sem efeito e não tenha restituído o que foi pago; para o usufrutuário que tenha melhorado a propriedade; para o possuidor que tenha construído ou plantado na propriedade de outro; para o credor anticresista, sobre o bem entregue para sua anticrese, até que não pague totalmente seu crédito (ESTEVEZ BRASA, 1985). No direito brasileiro o credor anticrético também tem o direto de reter o bem enquanto a dívida não foi paga, conforme artigo 1423, CCB.

\section{d) Privilégios}

O direito muçulmano concebe o direito de privilégio, ou seja, o direito de um credor a ser pago com preferência em relação aos outros, seja sobre o conjunto de bens do devedor, seja sobre algum bem determinado. Existem os privilégios gerais, que são os gastos com funerais e suplantam a todos os demais. Também há os privilégios especiais, que são da mulher e dos filhos menores para o pagamento de alimentos, embora nem todas as escolas reconheçam estes. Estes também têm privilégios especiais: o credor anticresista, o credor do penhor, o transportador sobre os objetos transportados, o obreiro sobre a obra que tenha produzido ou melhorado. Não há hipoteca no direito muçulmano (ESTEVEZ BRASA, 1985).

No direito brasileiro o credor de garantias reais, tais como penhor, hipoteca e anticrese, tem o direito de preferência no pagamento, a outros credores, com relação aos bens que foram dados em garantia, conforme artigo 1422, CCB. Mas as dívidas que devem ser pagas primeiramente em virtude de outras leis, como a ainda vigente lei de falências, preferem estas garantias. 


\section{Conclusão}

A observância da equidade como guia, as limitações ao usucapião e o apoio ao merecimento pelo trabalho permitem afirmar que a concepção de propriedade do Islan persegue a bonificação do homem. A necessidade de ceder a este pressuposto, frente a uma urgência de utilidade pública permissiva de expropriação não significa outra coisa que a afirmação da vigência da Comunidade Muçulmana e da fiel submissão que a ela devem seus filhos.

O objetivo deste trabalho era, de maneira bastante singela, apresentar um pouco do que é o direito muçulmano, quais as suas origens, seus fundamentos, suas fontes. Também o era apresentar um ramo específico do direito, o direito real, com a finalidade de buscar compreender o que significa a propriedade para o direito muçulmano e exemplificar trazendo alguns institutos que permeiam este direito.

Por fim, buscou-se de modo simples comparar alguns institutos do direito muçulmano com o direito brasileiro, com a finalidade de demonstrar que, embora com 'illa, ou razão do direito, seja muito diferentes em alguns aspectos, há institutos semelhantes e formas semelhantes de se resolver possíveis casos concretos.

O fim buscado não é exaurir o assunto ou discutir convergências e divergências doutrinárias, mas conhecer. Em tempos globais deve-se conhecer o que aparentemente está distante, deve-se buscar compreender a razão do diferente, pois conhecer é o primeiro passo para compreender e aprender a respeitar. E sem respeito não há justiça e não há direito.

\section{Referências bibliográficas}

LE SAINT CORAN. Tradução para o Francês por Dar Albouraq. Beyrouth-Liban: Dar Albouraq, 2008.

BADR, Gamal Moursi. La relance du droit islamique dans la jurisprudence algérienne depuis 1962. Revue internationale de droit compare. ano 21, n. 1, p. 43-54. jan./mar. 1970. 
CARICCHIO, José Renato. O direito muçulmano. Revista de direito do Tribunal de Justiça do Estado do Rio de Janeiro. Rio de Janeiro, v. 15, p. 74-82. 1993.

D'EMILIA, Antonio. Per uma comparazione fra diritto bizantino e muçulmano in materia possessória. In: Stude in onore di Vicenzo Arangio-Ruiz. Napoli: Jovene, s.d., p. 391-413.

DAVID. René. Lês grands systèmes de droit contemporains. 11 ed. Paris: Dalloz, 2002. p. 349-372.

ESTEVEZ BRASA, Teresa M. Derecho civil musulman, precedido de una introducion al advenimento del Islan. Buenos Aires: Depalma, $1981.630 \mathrm{p}$.

GOMES, Orlando. Direito Reais. Rio de Janeiro : Forense, 2000. $436 \mathrm{p}$.

PANSIER, Frédéric-Jérôme; GUELLATY, Karim. Le droit musulman. Que sais-je, Paris: PUF, 2000. 127 p.

SHACHT, Joseph. An introduction to Islamic Law. Oxford: Clarendon, 1975, $304 \mathrm{p}$.

SILVA, Justino Adriano F. da. Introdução ao direito muçulmano. Revista Estados Jurídicos - UNISINOS. São Leopoldo, v. 23, n. 62, p. 87-98. 1991

Recebido em: outubro 2011

Aprovado em: novembro 2011 